\title{
Impact of Modernization on Socio-economic Development of Manipuri Communities: A Sociological Studies
}

\author{
Mitu Chowdhury, ${ }^{1, *}$ \\ ${ }^{1}$ Department of Rural Sociology and Development, Faculty of Agricultural Economics and \\ Business Studies, Sylhet Agricultural University, Bangladesh \\ *Corresponding author: Department of Rural Sociology and Development, Faculty of \\ Agricultural Economics and Business Studies, Sylhet Agricultural University, Bangladesh. \\ Tel: 88-017-1695-7319. E-mail: mitu_bs@yahoo.com
}

Received: June 29, 2021 Accepted: July 19, 2021 Published: July 24, 2021

doi:10.5296/jsr.v12i2.18932ＵRL: https://doi.org/10.5296/jsr.v12i2.18932

\begin{abstract}
The Manipuri communities are very industrious. Very rich or extremely poor families are rare among them. So they do not work as day labourer or rickshaw puller. This is the expression of their modernism. This study was conducted an informative research work on the effects of modernization on the socio-economic development of Manipuri people. Five sampling areas were selected purposively - Kewa para, Sibganj, Noya bazar, Lama bazar and Sagar dighir par Manipuri para of Sylhet city in Bangladesh. Following a systematic sampling, a total number of 100 Manipuris participants were selected from the 20 families from each of the 5 sampling. This study also revealed that most of the respondents $73 \%$ have educational qualification between SSC to Master Degree. Above 28\% respondents are slight modern and $24 \%$ respondents are modern. So it proved that impact of modernization on profession. The observed that the Manipuri people are suffering from various diseases like diarrhoea, dysentery, gastric, coughing, rheumatic fever. Around highest $60 \%$ respondents are took allopathic treatment. It was a positive response to modernization. The finding of the current research might be helpful to future national policies of Bangladesh.
\end{abstract}

Keywords: impact, modernization, socio-economic development, Manipuri communities, sociological studies 


\section{Introduction}

In the modern world, some populations are still limitedly studied by us and those populations are eventually underprivileged. As a result, this underprivileged indigenous people exist with ancient life style. Besides, in most of the cases, these indigenous societies are far from modernization. For that reason, various social organizations are now concerned for the socio-economic development of these communities. But because of modernization Manipuri communities living on the plain land are markedly advanced than other comparatively backward indigenous people. In this Bangladesh of seasonal variations, there exists a variation among people as well as there are many tribes besides the main Bengali people. Among these tribes, the Manipuris are prominent. The modern Manipuri communities seem to have grown habituated with an independent state. At present, Manipur state is one of the prominent states of India. Although there is controversy regarding the time of settlement of the Manipuri tribe in Bangladesh, it is generally recognized that it took place very long ago. Internal conflict and invasion of the Manipuris caused them to spread over Sylhet, Dhaka, Mymensingh, Cumilla and different other regions. With the passage of time, they gradually established themselves in Dhaka, Mymensingh and Cumilla. Now the Manipuri people are scattered over different regions of Sylhet division only.

Many researchers studied various aspects of indigenous societies in Bangladesh, where a few of them conducted works on plain land Manipuris. So, I had a passion to work with plain land Manipuri communities. In addition, during the long period of my professional works in Sylhet Agricultural University, Sylhet, adjacent to various Manipuri communities, I was influenced logically to conduct a comprehensive research work on their livelihood and relationship. Many local people of Sylhet division living in some parts of England, America, Canada and other countries contribute to the national income through remittance. Manipuri people also live in these communities and modernization is bringing some radical changes to their life style as well. Besides, the pivotal objective of this research work is to unveil the impacts of modernization on Manipuri people and local inhabitants co-laterally.

So, the specific aim of this study is to evaluate the effect of livelihood changes within Manipuri people due to Modernization.

\subsection{Rationale of the Study}

It has already been stated that as a continuous process modernization has affected almost all sections of people irrespective of caste, tribe, religious or class identities. Among about fifty indigenous communities in Bangladesh, Manipuris are one of the highly educated and rapidly modernized groups. The components of modernization internalized, accepted and proliferated by the Manipuris are observed in many historical periods.

The Manipuris are currently treated as a plain land tribe which is gradually diminishing their alienations in terms of identity for nation in Bangladesh. The making, unmaking and restructuring of identity of the Manipuris are closely-related with their modernizing process.

In this process of constructing a nation the Sociological studies regarding the impact of Manipuri communities can be treated highly important and crucial. 
Since modernization is an unending process of social change, adoption of modernization is the life and livings of the Manipuris in a Bangalee dominated socio-economic milieu is really interesting to a researcher. The finding of the current research might be helpful to understand the problems of national integration of Bangladesh.

\subsection{Limitations and Contrariety}

It was very difficult to convince the Manipuri communities to face interview process for this study. It was hard also to convince them regarding the long lasting though not immediate benefits of this study. Their problems remain still unresolved although various researchers conducted their different studies on their livelihood, life style, cottage industries, micro finance etc. through oral interview and various discussions. They think that these studies will never lead them to sustainable development and so they are reluctant to face such interviews. But, they cordially participate in such interview if they are convinced through personal successful communication. Moreover, they have not got any written history through which we can assume their ancestry. So, we should depend on their verbal information. It is also noted that such researches are obviously little. Basically, a very few research works have been conducted on their current status. Despite such limitations, I would like to conduct an informative research and thesis work on the effects of modernization on the socio-economic development of Manipuri people. Information provided by the Manipuris about the effects of modernization process may be insufficient in this research work, but probably such type of research on Manipuri people is conducted for the first time in our country. Sometimes I have faced some difficulties to communicate with Manipuri indigenous people due to their language.

\subsection{Objectives}

The objectives of the present research -

First: To analyze the socio-economic parameters of the Manipuri communities - namely occupation, education, health etc.

Second: To get acquainted with the social status of the Manipuris.

Third: To observe the extent of influence of modernization on the life style of the Manipuris.

\section{Research Methodology}

The data were collected by using both qualitative and quantitative methods aimed at assessing the overall situation, needs and difficulties encountered by the Manipuri community. Here the qualitative purpose kinds of data collection techniques were used: (1) In-depth open-ended interviews (2) Direct observation (3) Focus Group Discussion (FGD). At the beginning are the important sources of qualitative information of data collection. To meet this end, data collection techniques were used for the research-

i) Individual, face to face interview with household heads 
ii) In-depth interviews with the experienced and educated elders

iii) Direct observation

iv) An open-discussion on findings in the presence of researchers academics, Manipuri community leaders, journalists and some other respectable citizens belonging to the civil society.

Besides, other secondary data for this study were collected from different manual and government documentation. The study has mainly focused on the impact of modernization on the Manipuri community. For quantitative purpose we used questionnaire techniques. More over data available in secondary sources such as BBS, District gazette etc. were used.

\subsection{Research Design}

As the subject of the research is the impact of modernization, population of the Sadar Upazila of Sylhet town has been selected considering the relation between modernization and urbanization. Besides this, those areas have good communication with Sylhet Sadar. Pilot survey has been conducted at first as during the process of data collection for questionnaire, some data have been included and some have been omitted for research purpose. Different tools have been used in data collection. Rapport building was impartial. G.S. Bhatnagar and S.L. Sharma methods have been used in research.

\subsection{Survey area Selection}

Considering the time allotted for research, financial condition, man power availability, convenience of collecting data and five sampling areas were selected purposively, - namely, Kewa para, Shibganj, Noya bazar, Lama bazar and Sagar dighir par Manipuri para of Sylhet district were selected as study area. Following a systematic sampling scheme, a total number of 100 Manipuris participants were selected from the 20 families from each of the five sampling areas.

\subsection{Modernization}

Modernization has been given special importance for the development of the underdeveloped and third world countries. A class of western sociologist believes that, development of third world countries is only possible through modernization. This modernization means westernization. Recently, modernization refers to Americanization. Simple meaning of modernization is to transform underdeveloped countries in the form and features of developed countries. Most of the countries of the world attained their independence after World War II. They were colonies of developed countries. Some of these countries adopted socialism as economic system after their independence. Some other countries adopt the mixed economy and subsequently depended on indicative planning. The newly independent countries, which adopted mixed economy and indicative planning, are usually called "third world" countries. They can also be called "as underdeveloped society." Recently, they have been given a respectful name as developing society. Gunner Myrdal has termed it as terminological diplomacy. There are various intellectuals who termed these societies as 
traditional societies in the process of transition to modernity.

After World War II, the countries of the world were divided into three divisions.

Namely:

A. Countries with centrally planned economy.

B. The developed capitalist countries with market economy

C. The undeveloped countries or what is broadly called the third world (Alam, 2000).

Sociologists think that, modernization is initiated through the changing process.

Just like development, it is difficult to define modernization. The concept of modernization is ancient but its systematic study is very recent. Most of the Sociologists were excited to explain the wave of state development after Second World War. Economists, Sociologists and Political Scientists explained those changes, intensity of changes, problem, and solution from their different point of views. Most of the social changes of that time were brought about by the modernization revolution (Begum, 2004).

\subsection{Daniel Lerner}

Daniel Lerner describes four things as component or indicators of modernization. These are urbanization, literacy, media participation and political participation. Whilst describing the signs of modernization, Daniel stated "According to this typology, the modern person is an urbane literate who participates fully in the public forum, market place, political arena (Lerner, 1964).

According to Daniel Lerner, modernization process changes the traditional behaviour of a person through empathy. Empathy is simply a quality of a person to replace him in the place of other. Empathy is the precondition of modernization. According to Daniel Lerner, empathy is intermediary between mass communication and modernization. Empathy is viewing oneself in others place. Here, communication takes place between two individuals. We communicate from the interest of knowing others. To understand Traditional and Modern society we need to place our self in two locations. In a Traditional society, community of receiver and sender are less effective. By observing the living style of underdeveloped countries we can understand the relations between communities.

Thus, mass media and modernization are mutually dependent concept. Exposure to mass media leads a society towards modernization. Along with Mass many other preconditions is associated with modernization. From the following table a clear understanding can greatly be attained.

Empathy theory of Daniel Lerner reflects the modernization of Manipuri society through the exposure of mass media. Thus, impact of modernization is visible among them. 
$\underline{\text { Antecedents }}$

Mass Media

i) Functional Literacy

Consequences

ii) Mass Media Exposure

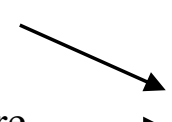

iii) Cosmo politeness

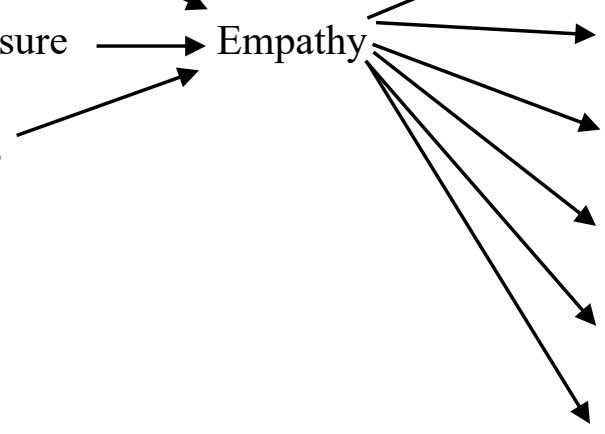

Innovativeness

Achievement motivation

Political knowledge ability

Opinion leadership

Aspiration

Manipur remained independent long time after starting British rule in India. They always live in plain land and they have enlightened history and tradition of an enriched language, literature and culture. From observation it is seen that in greater Sylhet, literacy rate of the Manipuris are higher than other tribes which is at present $81 \%$ and their access to higher education has significantly increased.

The Manipuris are very industrious. Very rich or extremely poor families are rare among them. So they do not work as day labourer or rickshaw puller. This is the expression of their modernism.

It seems that due to the effect of modernization, the Manipuris are advancing better than other tribes.

\section{Findings and Discussion}

Manipuri community is male dominant like the majority of population of Bangladesh. Males have the sole authority regarding family and community affairs. However females are not neglected, they have a good respectable position within the family. In community affairs, females can play the role of participants but decisions and their execution are reserved for males. Community leadership is reserved for the older people who must be male (Ahmmed et al. 2007).

The result followed a combination of quantitative and qualitative data analysis.

\subsection{Educational Qualification}

Level of education is very low in Bangladesh. Poverty is one of the major factors for the low education rate in Bangladesh. Since most of the Manipuris cannot afford higher education, they choose their traditional cottage industry as a means of livelihood. However, because of rapid expansion of higher education, Manipuri partipation in secondary and tertiary economic sectors are gradually increasing. Among Manipuris survey in 1979 shows that the number of 
employee was about 3\%. At present this percentage is remarkable. Manipuri employees are now in different occupation. Among them there are doctors, engineers, high officers of different Govt. and financial institutions, lawyers and teachers. In terms of occupation, the number of teachers are high among employees (Sheram,2006).

Table 1. Information about the Educational Qualification of Respondents

\begin{tabular}{lll}
\hline Educational qualification & No. of respondent & Percentage (\%) \\
\hline Illiterate & 05 & 5.00 \\
Able to sign. / Signers & 06 & 6.00 \\
Class I - V & 16 & 16.00 \\
SSC & 40 & 40.00 \\
HSC & 20 & 20.00 \\
Graduate & 10 & 10.00 \\
Post-graduate & 03 & 03.00 \\
Total & 100 & 100.00 \\
\hline
\end{tabular}

Source: Survey area, Syhlet

From the above table it is clear that most of the respondents (73\%) in the research area have educational qualification between SSC to Masters Degree. From this it can be assumed that the rate of education in Manipuris are much higher than that of other tribal communities, which is comparable to the plain land Bangalees. Nowadays many Manipuris are found in some prestigious professions like medical, engineering and higher education sectors.

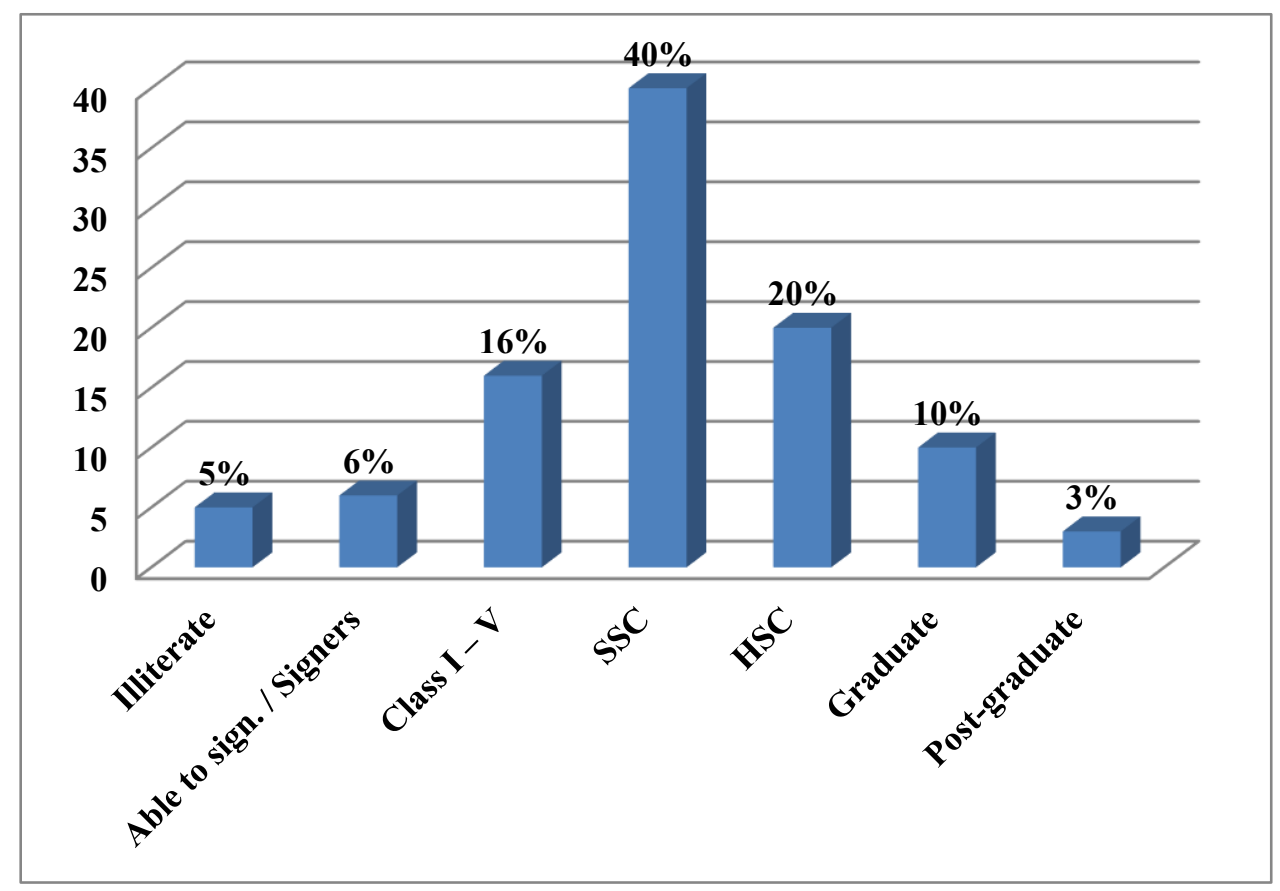

Figure 1. Information about the Educational Qualification of Respondents 


\section{Macrothink Institute ${ }^{\mathrm{TM}}$}

G.S. Bhatnagar and S.L.Sharma methods have been used in research. From the answers of respondents, the responses are scored between 1 to 5 . In this way a respondent is able to get the lowest of 25 to the highest score of 55. On the basis of such score, the degree of a person's level of modernization can be marked as follows -

a. Most rigid (score: 25-29)

b. Rigid (score: $30-34$ )

c. Slightly modern (score: 35 - 39)

d. Modern (score: $40-44)$ and

e. Most modern (score: $45+$ above)

Such measurement of modernization was used by D'souza (V.S. D'souza, Measurement of Rigidity- Fluidity Dimension of social stratification in six India villages, 1964, Sociological Bulletin, vol.18(1), p. 35-49, (Bhatnagar, 1972) \& Sharma (Sharma, 1979).

Present research followed the tactics of S.L. Sharma-

Little bit educated: Class I to class V

Moderated educated: Class V to class X

Educated: SSC to Masters

Table 2. Parameter of Education \& Modernization

\begin{tabular}{lllll}
\hline Level & Rigid & Slight Modern & Modern & Total \\
\hline $\begin{array}{l}\text { Illiterate } \\
\text { Little }\end{array}$ & $08(36.36 \%)$ & $06(27.27 \%)$ & $08(36.36 \% 0$ & $22(22.00 \%)$ \\
$\begin{array}{l}\text { educated } \\
\text { bit }\end{array}$ & $26(44.82 \%)$ & $22(37.93 \%)$ & $10(17.24 \%)$ & $58(58.00 \%)$ \\
$\begin{array}{l}\text { Total } \\
\text { Totaled }\end{array}$ & $14(70.00 \%)$ & - & $06(30 \%)$ & $20(20.00 \%)$ \\
\hline
\end{tabular}

Source: Survey area, Syhlet

Data from above table shows a relationship between education and modernization. At present most rigid situation is absent. 


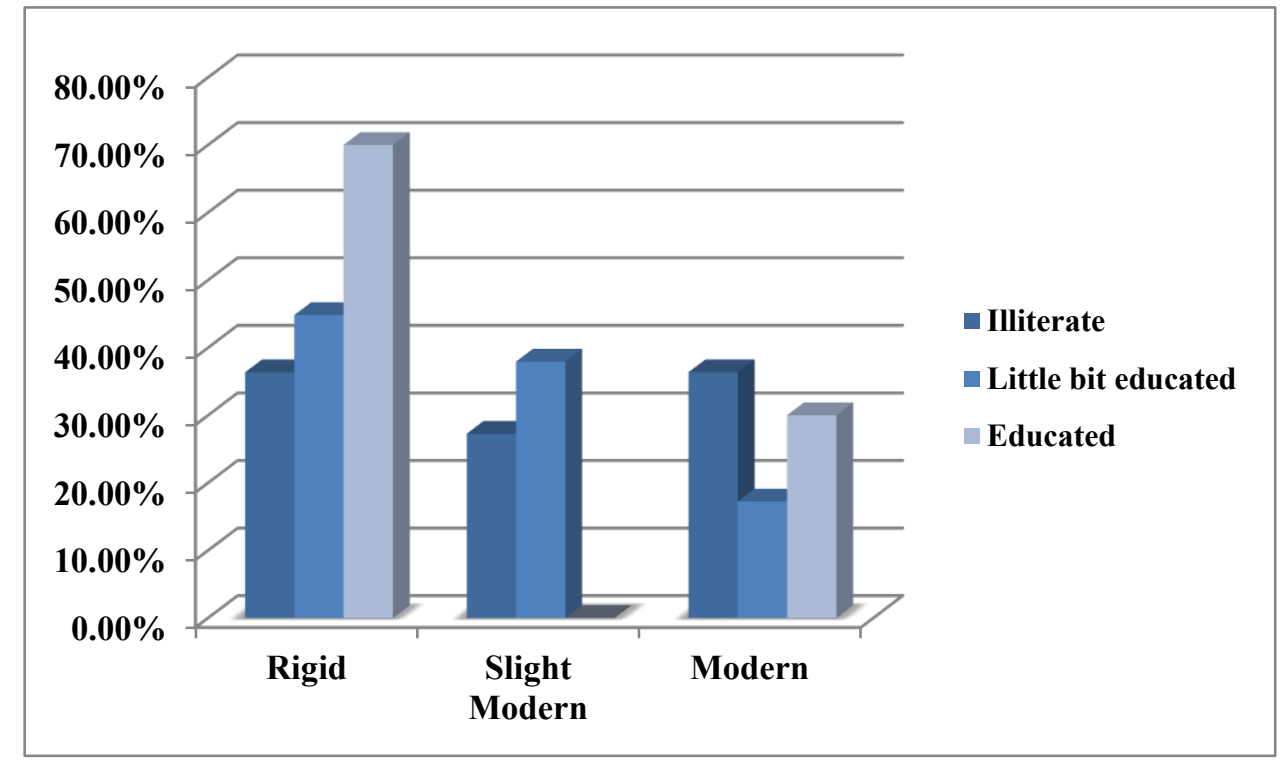

Figure 2. Parameter of Education \& Modernization

\subsection{Occupation}

Manipuris live in plain lands, not only in Bangladesh, but also in their ancient place of origin'Manipur', the eastern mountain state of India. In Bangladesh $80 \%$ of Manipuri live in villages and agriculture is their means of living. While in urban areas, they are mainly goldsmith or motor mechanic. Most of the city dweller Manipuris have gold jewellery shop. Those who have no jewellery shop work as goldsmith in other shops. Once upon a time Manipuris had the supremacy in gold jewellery business and motor repairing. In course of time such supremacy is no longer but still many local and old persons depend on Manipuri goldsmith and motor mechanics for their excellence in work and loyalty. Moreover, many Manipuri in city and village are carpenters. As a carpenter their skill and efficiency were hearsay. In this context a quote of B.C Allen form Sylhet District Gazette can be mentioned. He said "The best carpenters are Manipuris and they often enrich the boxes and bed stead's they turn out with a little carving" (Allen, 1905).

Manipuri women are very laborious. In some sectors they work harder than the male. Being an efficient household worker, they not only do their household works but also support the male in field work. Males plough the land and females sow the seed. Again when the grain ripes, both male and female join in reaping. Beyond their daily business, the Manipuri women involve themselves in some capital earning activities.

In terms of economics, the Manipuris generally belong to the lower middle to middle-class category. They are hard-working. As a result everybody do some sort of work for livelihood. Social outlook also cooperate in this sense, because of strong social solidarity among them. So, they have no involvement in begging, theft, robbery and other socially despicable activities. For prestige they do not involve themselves in day labouring, rickshaw pulling or such activities. Moreover, in Manipuri society there is no example of working as a labourer at 


\section{Macrothink}

other man's house or toiling as a household-worker. Again it is socially prohibited to engage any person from other society for doing house hold works. So, Manipuri women must complete all the domestic duties even if she is the wife of a rich man or any high official.

Table 3. Respondents Professional Status

\begin{tabular}{lcc}
\hline \multicolumn{1}{c}{ Types of profession } & No. of respondent & Percentages $(\%)$ \\
\hline Student & 06 & 06.00 \\
House wife & 16 & 16.00 \\
Farming (Agriculture) & 40 & 40.00 \\
Handicrafts & 20 & 20.00 \\
Business & 08 & 08.00 \\
Govt. / NGO employee & 08 & 08.00 \\
Retired employee & 02 & 02.00 \\
Total & 100 & 100.00 \\
\hline
\end{tabular}

Source: Survey area, Sylhet

It is obvious from the research that most of the respondents are engaged in farming and handicraft activities. Some showed interest in business. But one positive side is that a lot of Manipuris bring their traditional handicrafts in modern competitive market.

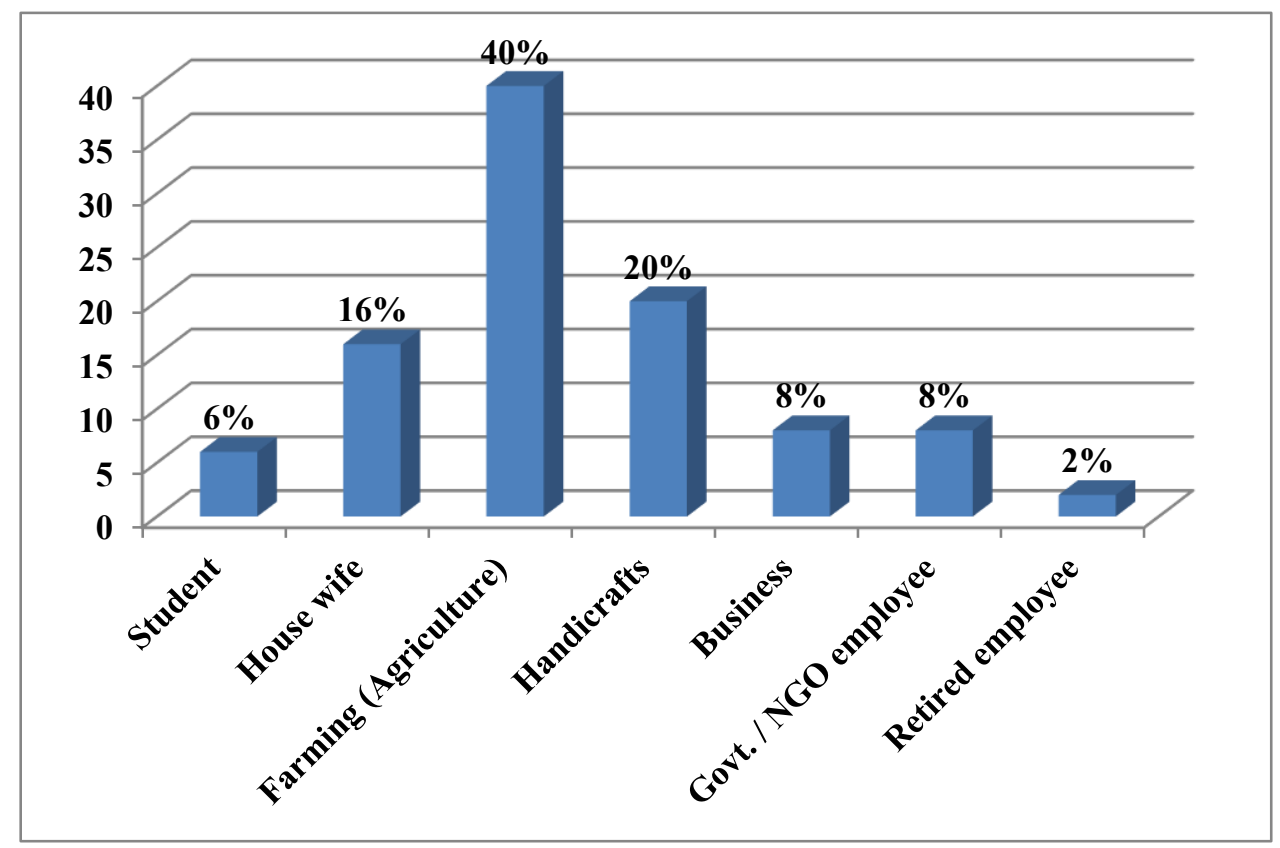

Figure 3. Respondents Professional Status 
Table 4. Respondents Profession and Measurement of Modernization

\begin{tabular}{lcccc}
\hline \multicolumn{1}{c}{ Profession } & Rigid & Slight Modern & Modern & Total \\
\hline Agriculture & $12(42.85 \%)$ & $08(28.57 \%)$ & $08(28.57 \%)$ & $28(28.00 \%)$ \\
Handicrafts & $20(43.47 \%)$ & $14(30.43 \%)$ & $12(26.08 \%)$ & $46(46.00 \%)$ \\
Business & $10(62.50 \%)$ & $04(25.00 \%)$ & $02(12.50 \%)$ & $16(16.00 \%)$ \\
Employee (GO & $06(60.00 \%)$ & $02(20.00 \%)$ & $02(20.00 \%)$ & $10(10.00 \%)$ \\
/NGO) & - & - & - & - \\
House wife & $48(48.00 \%)$ & $28(28.00 \%)$ & $24(24.00 \%)$ & $100(100.00 \%)$ \\
Total & & & &
\end{tabular}

Source: Survey area, Sylhet

From analysis of above data it is seen that most of the Manipuris are engaged in agricultural $\&$ handy work. It is also mentionable that majority of the respondents (48\%) are rigid and $24 \%$ are modern. So, it proves the impact of modernization on profession.

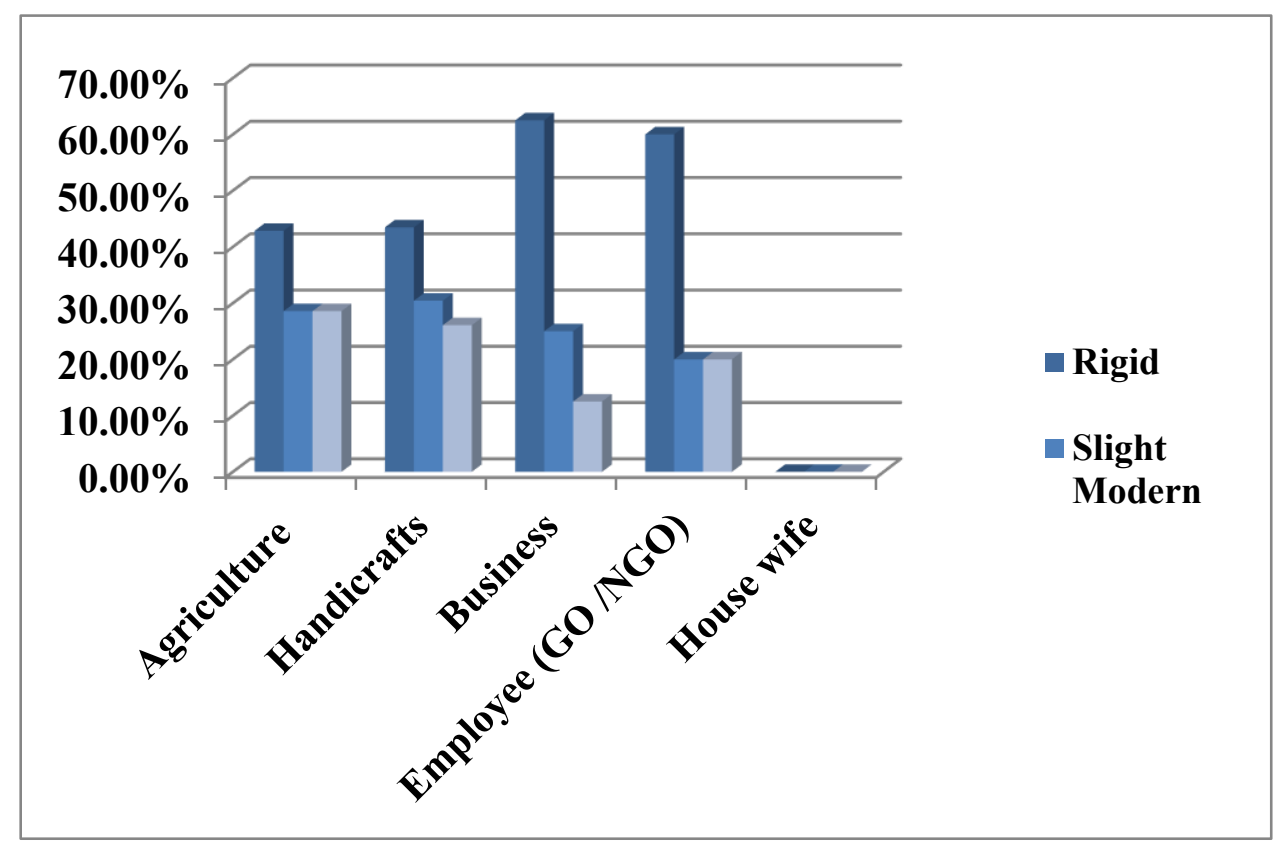

Figure 4. Respondents profession and measurement of modernization

Table 5. Respondents Socio-economic Condition and Measurement of Modernization

\begin{tabular}{lcccl}
\hline \multicolumn{1}{c}{$\begin{array}{c}\text { Community \& } \\
\text { Socio-economic condition }\end{array}$} & Rigid & $\begin{array}{c}\text { Slight } \\
\text { Modern }\end{array}$ & Modern & \multicolumn{1}{c}{ Total } \\
\hline Lower & $10(50.00 \%)$ & $06(30.00 \%)$ & $04(20.00 \%)$ & $20(20.00 \%)$ \\
Middle & $20(40.00 \%)$ & $14(28.00 \%)$ & $16(32.00 \%)$ & $50(50.00 \%)$ \\
Higher & $14(46.66 \%)$ & $10(33.33 \%)$ & $06(20.00 \%)$ & $30(30.00 \%)$ \\
Total & $44(44.44 \%)$ & $30(30.00 \%)$ & $26(26.00 \%)$ & $100(100.00 \%)$ \\
\hline
\end{tabular}




\section{Macrothink}

Source: Survey area, Sylhet

Table 5 shows that, Manipuris communities have seen a few lower class than middle and upper class. It is proved that, there are visible modern amenities in life.

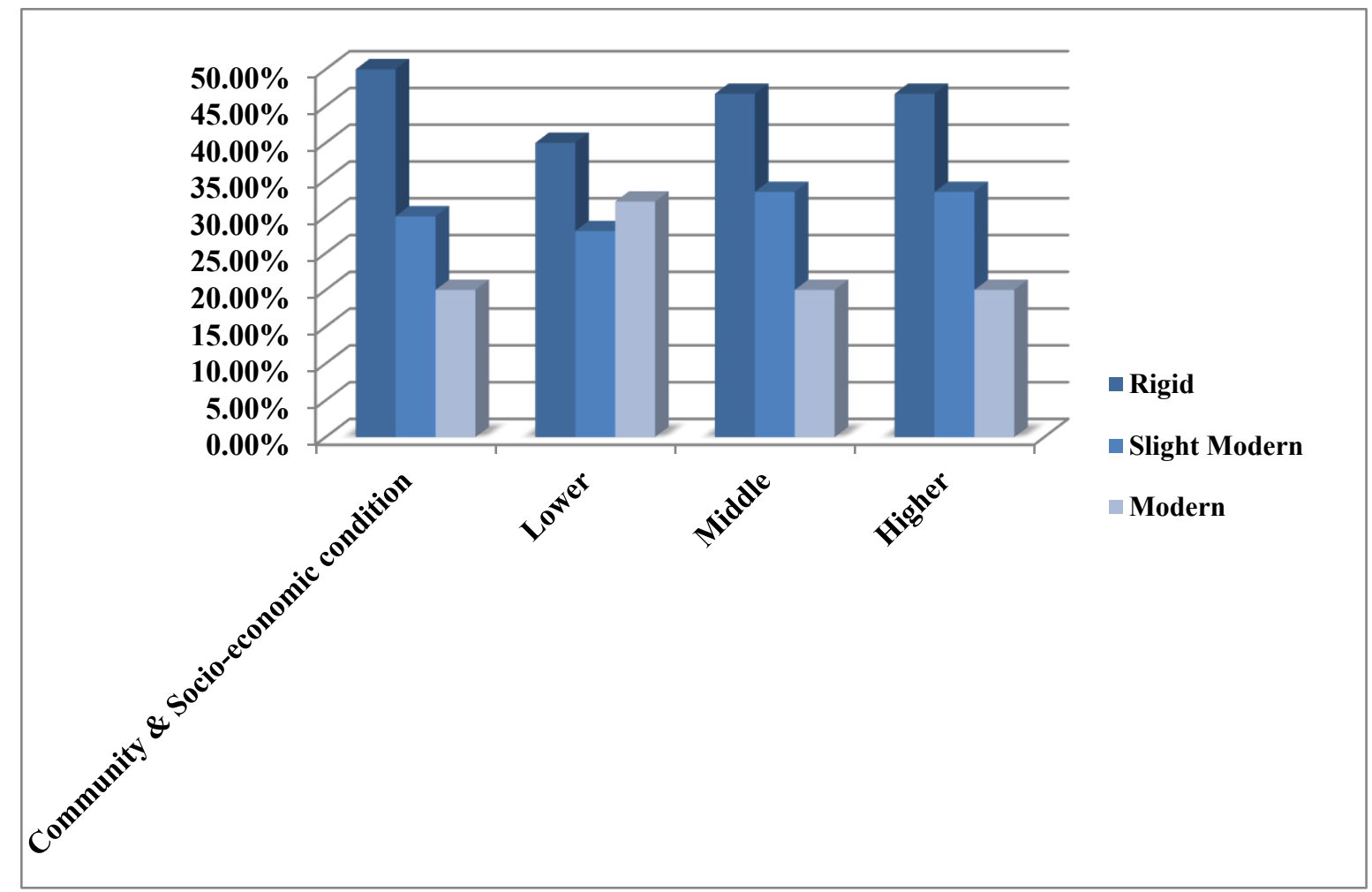

Figure 5. Respondents Socio-economic Condition and Measurement of Modernization

\subsection{Health}

Treatment is one of the prime needs of man. In whatever situation they will be, it is very normal that they will seek treatment when sick. Such illnesses are of various types. For example: diarrhoea, dysentery, gastritis, flu, cough, fever, rheumatic fever etc. Illness occurs due to irregularities in life and food intake.

Table 6. Types of Illness / Disease

\begin{tabular}{lcc}
\hline \multicolumn{1}{c}{ Name of the disease } & No. of respondents / frequency & Percentage (\%) \\
\hline Diarrhea & 28 & 28 \\
Dysentery & 28 & 28 \\
Gastritis & 20 & 20 \\
Sneezing \& coughing & 20 & 20 \\
Rheumatic fever & 02 & 02 \\
Others & 02 & 02 \\
Total & 100 & 100 \\
\hline
\end{tabular}




\section{Macrothink}

Source: Questionnaire survey, Sylhet

Above table shows that, 28 respondents among 100 are suffering from diarrhoea i.e.28 (28\%) from dysentery $28(28 \%)$, gastritis $20(20 \%)$, sneezing \& coughing 20(20\%), rheumatic fever $02(02 \%) \&$ others $02(02 \%)$.

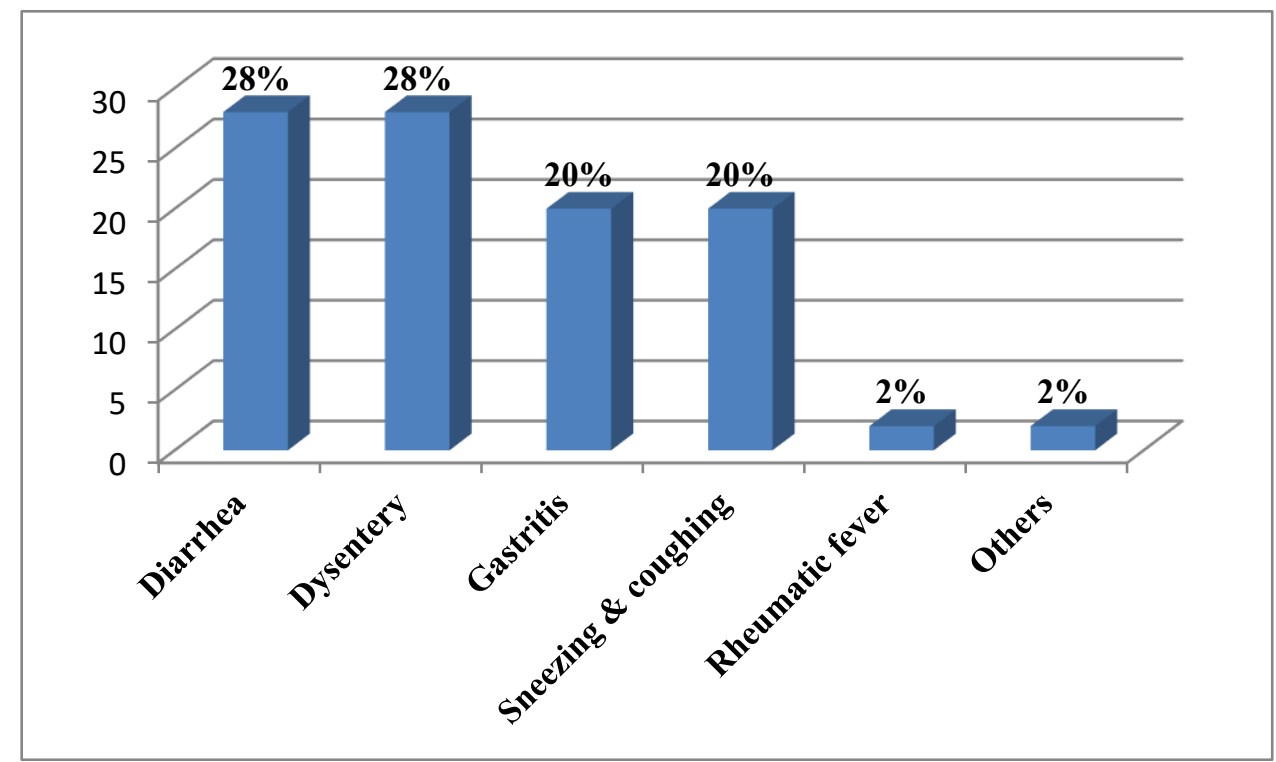

Figure 6. Types of Illness / Disease

\subsection{Treatment System}

Manipuri people are health conscious. Their food habit is healthy and generally consists of a balanced diet.

Table 7. Relation between Health Services to Modernization

\begin{tabular}{lcc}
\hline \multicolumn{1}{c}{ Treatment type } & No. of family & Percentage $(\%)$ \\
\hline Allopathic & 60 & 60.00 \\
Homeopathic & 30 & 30.00 \\
Ayurvedic / Kabiraji & 10 & 10.00 \\
Total & 100 & 100.00 \\
\hline
\end{tabular}

Source: Survey area, Sylhet

It is apparent from the above table that 60 Manipuri families took allopathic i.e. $60 \%$ \& the rest of the families took Homeopathic treatment. I. e. $30 \%$. The younger generation's attitude is changing and they are becoming more familiar with modern medical facilities and their use. It shows a positive response to modernization. 


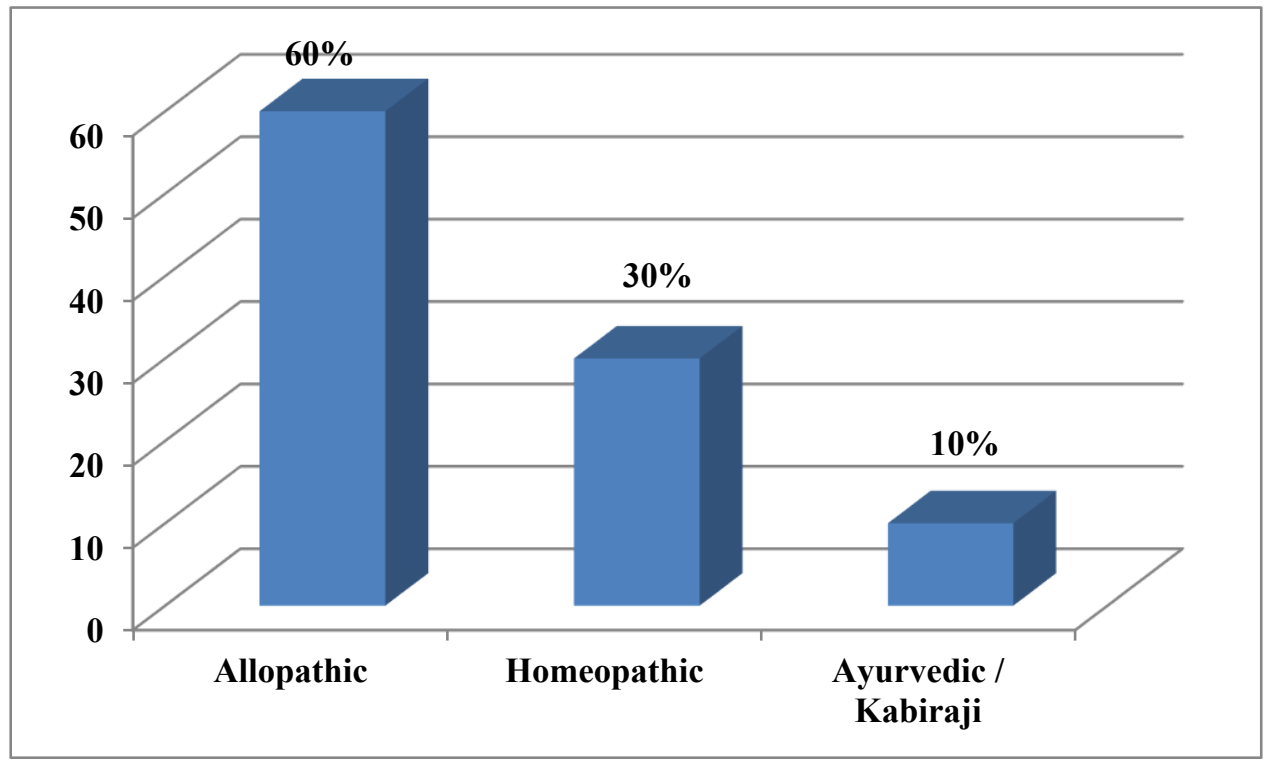

Figure 7. Relation between Health Services to Modernization

\subsection{Context of Constitutional Recognition in Bangladesh}

Bangladesh Indigenous People Forum was established on July 13, 2001. The forum has started its journey with the motto, not only human rights - unity, solidarity and progress for the freedom of the indigenous people who are ever deprived from the fundamental rights of human.

In today's world, Manipuri education system bears a good fame. It is mentionable that Manipuri language is the medium for secondary education and exam under Board of Secondary Education in Manipur and Assam. Besides this Delhi Central Board of Secondary Education, The Board of school Examination west Bengal, The Mijorum Board of school Education also approved Manipuri language as a major subject in Indian languages. Moreover, Manipuri language is recognized by famous Universities of India like Kolkata University, Gowhati University, Delhi University, North-Bengal University, North - Eastern Hill University and Dibrugor University. At present, B.A (Hons.), Post-graduate, M.Phil, Ph.D degrees are given in 'Meitheilan' or 'Manipuri' language.

In Indian constitution, Meitheilan or Manipuri language as a scheduled language is worth mentioning among other eighteen established languages (Drong,2006). Meitheilan language is constituted of 18 alphabets. They learn it from their family. A census shows that Manipuris are quite alert about education. But in Bangladesh there is no separate institute for education of Manipuris.

The Common tendency in Bangladesh is to give emphasis on the indigenous groups who live in Chittagong hill tracts. But plain land indigenous people and indigenous people of the other parts of Bangladesh are getting less attention from both government and non-government organizations. This disparity should be addressed properly by the concerned authorities. We have the glorious and unique history to protect language and among indigenous community, 
it will be possible once basic education is introduced to them in their mother language. It can increase education among those communities and this increased rate of education/educated people will in turn have multiple effects in their life and livelihood (Annual Review of Ethnic Affairs, 2011).

\section{Conclusion and Recommendations}

Among the ethnic minority of Bangladesh, Manipuri is prominent. Recently, like the main esteem Bangladeshis, modernization is observable in the Manipuri society. This might be due to the engagement and close contact of their members to different education, occupation and treatment. However, driving force of their modernization is focused on their own education, profession and treatment. Although, as influence of the modern capitalist social system, modernization is visible in the Manipuri society - they have successfully preserved their traditional occupation loom industry through its modernization. If they receive patronization from the government, they will be able to contribute more to the national economy. In the research area, we found that many Manipuris have received modern education and are engaged in respectable professions. This has an impact on their life style and has significantly driven them towards modernization. Their presence in the plain land has created social relationship with the main stream of the society. For this reason, the Manipuri tribe is well advance in the race of modernization than the rest of the ethnic minorities in Bangladesh. There is no participation from Manipuri's among the policy makers and planners of the country. Gradually they are being pushed farther away. We have-not yet taken any initiative to embrace these people who are living with landless feelings in their own land. Thus, it can be undoubtly stated that the influence of modernization and modern capitalist industrial society on Manipuri society is clearly visible. People in the main areas are changing their profession and traditional cultural life style.

\subsection{Recommendations}

For the development of the Manipuri society, following recommendations might be considered with importance-

1. The constitutional recognition of the indigenous is necessary. It is necessary to establish indigenous ministry or commission - which will be governed by the elected or selected representative from the indigenous.

2. It is important to implement the Vested Property Return Act 2002. Seized land and properties due to the Enemy/ Vested Property act need to be returned to appropriate successors.

3. To develop the health sectors of Manipuri society, sinking tube wells for safe drinking water and introduction of sanitary latrines can be considered.

4. Government and NGO'S should take proper awareness programme with the help of mass media on social education for the development of the Manipuri society. 
5. For understanding the complete scenario, and to ensure the healthy and normal environment for underprivileged Manipuris of the country - political, social and religious leaders as well as the civil society should play a vibrant role.

Finally, government needs to address the recommendations immediately. Implementation of the recommendations will help the Manipuri people to play important role in the development of the country in coming years.

\section{References}

Alam, K., \& Unnyanmulak, S. (2000). Minavaa Publications. Dhaka, Bangladesh, 118-119.

Ahmmed, M. F., \& Lakshmi kanta, S. (2007). State of the Ethnic Community Development Organization. Sylhet, Bangladesh, 79.

Allen, B. C., Assam District Gazette - C.S.(1905). Calcutta. India, ii, 157.

Annual Review of Ethnic Affairs (August 2011).Ethnic Community Development Organization (ECDO). Sylhet, Bangladesh, VII, 26.

Begum, F. (2004). Shamajik Paribottan O Rajnaitik Unnyan. Kakoli prokashoni, Dhaka, Bangladesh, 37.

Bhatnagar, G. S. (1972). Education and Social Change. the Minerva Associates, Calcutta, India, 103.

Sanjib, D. (2006). Deshhin Manusher Kotha. Adibashider Bonchona O Sangrami Khhini, Shucipatro, Dhaka, Bangladesh, 42-44.

Lerner, D. (1964). The Passing of Traditional Society. Free Press, New York, 19-22.

Sheram, A. K. (2006). Bangladesher Manipuri. Aagami Prokashoni, Dhaka, Bangladesh, 66.

Sharma, S. L. (1979). Moderning Effects of University Education. Allied Pvt. 1td., Bombay, India, 85.

\section{Copyright Disclaimer}

Copyright for this article is retained by the author(s), with first publication rights granted to the journal.

This is an open-access article distributed under the terms and conditions of the Creative Commons Attribution license (http://creativecommons.org/licenses/by/3.0/). 